Research Article

Mutagenesis

\title{
Cis-trimethoxystilbene, exhibits higher genotoxic and antiproliferative effects than its isomer trans-trimethoxystilbene in MCF-7 and MCF-10A cell lines
}

\author{
Natália dos Santos Gonçalves ${ }^{1}$, Tamires Maria Silva Pereira de Melloํㅡ, Cássia Suemi Mizuno², \\ Saqlain Haider ${ }^{3}$ and Raquel Alves dos Santos ${ }^{1}$ \\ ${ }^{1}$ Universidade de Franca, Laboratório de Genética e Biologia Molecular, Franca, SP, Brazil. \\ ${ }^{2}$ University of New England, Westbrook College of Health Professions, School of Pharmacy, Department \\ of Pharmaceutical and Social Administrative Sciences, Portland, ME, USA. \\ ${ }^{3}$ University of Mississippi, School of Pharmacy, National Center for Natural Products Research, MS, USA.
}

\begin{abstract}
Stilbenes are a class of natural compounds with a wide variety of biological effects, such as antitumor activity. The best-known stilbene is resveratrol, whose clinical application is limited due to its low bioavailability. Methoxylated derivatives of this stilbene, including cis-trimethoxystilbene (cis-TMS) and trans-trimethoxystilbene (trans-TMS) have demonstrated more pronounced cytotoxic and anti-proliferative effects than resveratrol. Thus, the objective of this study is to evaluate and compare the cytotoxicity and antiproliferative effects of cis- and trans-TMS in MCF-7 and its normal counterpart MCF-10A. Both compounds were cytotoxic, genotoxic, and induced G2-M accumulation and cell death in the two cell lines. These results suggested that the genotoxicity of cis-and trans-TMS is involved in the reduction of cellular proliferation of MCF-7 and MCF-10A cells, but notably, such antiproliferative effects are more pronounced for cis- than trans-TMS.
\end{abstract}

Keywords: Stilbenes, genotoxic, cell cycle arrest, apoptosis.

Received: January 12, 2021; Accepted: June 28, 2021.

\section{Introduction}

Natural products are an important source of bioactive agents of diverse structures and biological activities. They represent the most abundant reserve of molecules for the development of drugs in clinical use (Almaliti et al., 2013). Considering the 174 new anticancer drugs discovered between 1981 and 2014, 136 were originated from or based on natural products (Cragg and Newman, 2016). New cancer therapies are needed to overcome drug resistance in some of the existing treatments, and also to find drugs that are safer and less toxic to non-tumoral cells (Lin et al., 2017).

The stilbenes are among the natural compounds with great pharmacological potential. The most studied stilbene is resveratrol, a polyphenolic compound found in a wide variety of plant species such as grapes, blueberries, among others (Rivière et al., 2012; Elshaer et al., 2018; Mikstacka et al., 2018). Studies have demonstrated the biological potential of resveratrol such as anti-oxidant, anti-inflammatory, cardioprotective and anti-tumor activities (Paul et al., 2010; Elshaer et al., 2018). It has been shown that this stilbene acts at all three stages of carcinogenesis (initiation, promotion, and progression) by modulating cell division and growth control pathways, apoptosis, inflammation, angiogenesis and metastasis (Shukla and Singh, 2011).

Despite these promising effects, in vivo studies have shown that issues such as poor bioavailability due to quick

Send correspondence to Raquel Alves dos Santos. Universidade de Franca, Laboratório de Genética e Biologia Molecular, Av. Dr. Armando Salles de Oliveira, 201, 14404-600, Franca, SP, Brazil. E-mail: rasantosgen@yahoo.com.br. metabolism can hamper the clinical use of resveratrol; this problem can be overcome using polymeric and lipid nanoparticles to improve the oral bioavailability of resveratrol (Intagliata et al., 2019). Some structural modifications of resveratrol have aimed to increase its potency (Fulda, 2010). Therefore, chemical modifications in the resveratrol structure are related not only to overcome the bioavailability but to improve its biological activity (Tian and Liu, 2020). Structureactivity relationship studies have shown that the substitution of the hydroxyl groups of resveratrol by methoxy groups improves the antitumoral potential of the compounds and increases cytotoxicity against lung and colon carcinoma cell lines (Fulda, 2010; Paul et al., 2010). Thus, two methoxylated derivatives of resveratrol have been synthesized and tested: the (Z)-1,3-dimethoxy-5-(4-methoxystyryl)benzene (cis-TMS) and (E)-1,3-dimethoxy-5-(4-methoxystyryl)benzene (transTMS) (Figure 1). Some resveratrol derivatives, including trimethoxystilbene acted as a tubulin depolymerizing agent inducing mitotic delay and mediating the production of multipolar spindles that caused the mitotic catastrophe and cell death in HeLa cells (Traversi et al., 2017). Cis-TMS also increased the micronucleus frequency in CHO-K1 and HepG2 cells, demonstrating its genotoxic effects (Mizuno et $a l ., 2017)$. As well known, cancer treatment is based on the use of genotoxic agents (Connor, 2015). Despite the evidence that trans-TMS blocked the epithelial-mesenchymal transition of the tumoral breast cell line MCF-7, no current data is reporting the antiproliferative effects of cis-TMS in this cell line. In the present study, we tested and compared the antiproliferative effects of cis-and trans-TMS in the mammary adenocarcinoma cell line (MCF-7) and its standard counterpart (MCF-10A). 


\section{Material and Methods}

\section{Synthesis of stilbenes}

The stilbenes were synthesized as previously published (Mizuno et al., 2008). Shortly, to a cold solution $\left(-78^{\circ} \mathrm{C}\right)$ of phosphonium salt (1.0 equivalent) in anhydrous THF was added $n$-butyllithium ( $1.6 \mathrm{~mol}$ in hexane, 1.0 equivalent) and the resulting solution was stirred under inert atmosphere for $2 \mathrm{~h}$. A solution of aldehyde (1.0 equivalent) in THF was added dropwise, and the mixture was stirred for $12 \mathrm{~h}$ at room temperature. The resulting suspension was poured into water and extracted with dichloromethane. The organic phase was combined and dried over $\mathrm{MgSO}_{4}$, and concentrated under reduced pressure. The crude product was purified through automated flash purification elution with hexane/ethyl acetate.

Trans-TMS. ${ }^{1} \mathrm{H} \mathrm{NMR}\left(\mathrm{CDCl}_{3}, 300 \mathrm{MHz}\right): \delta 3.83(\mathrm{~s}, 9 \mathrm{H})$; $6.37(\mathrm{t}, 1 \mathrm{H}, J=2.1 \mathrm{~Hz}) ; 6.65$ (d, $2 \mathrm{H}, J=1.8 \mathrm{~Hz}) ; 6.87-6.89$ $(\mathrm{m}, 2 \mathrm{H}) ; 6.92(\mathrm{~d}, 1 \mathrm{H}, J=5.1 \mathrm{~Hz}) ; 7.04(\mathrm{~d}, 1 \mathrm{H}, J=16.2 \mathrm{~Hz})$; 7.45 (d, 2H, $J=6.9 \mathrm{~Hz}) .{ }^{13} \mathrm{C} \mathrm{NMR}(\mathrm{CDCl} 3,75 \mathrm{MHz}): \delta 55.2$ (3C), 99.7, 104.2 (2C), 114.2 (2C), 126.5, 127.8 (2C), 129, 130, 139.6, 159.4, 161.0 (2C). LC-MS m/z 270.19. (M+H) ${ }^{+}$.

Cis-TMS. 1H NMR(CDCl, $500 \mathrm{MHz}): \delta 3.71(\mathrm{~s}, 6 \mathrm{H})$; 3.81 (s, 3H); 6.36 (t, 1H, $J=5 \mathrm{~Hz}) ; 6.47-6.50$ (m, 3H); 6.57 $(\mathrm{d}, 1 \mathrm{H}, J=10 \mathrm{~Hz}) ; 6.81(\mathrm{~d}, 2 \mathrm{H}, J=10 \mathrm{~Hz}) ; 7.26(\mathrm{~d}, 2 \mathrm{H}, J=10$ $\mathrm{Hz}) .{ }^{13} \mathrm{C} \mathrm{NMR}\left(\mathrm{CDCl}_{3}, 125 \mathrm{MHz}\right): \delta 55.2$ (3C), 99.6, 106.6 (2C), 113.5 (2C), 128.7, 129.5, 130.2, 130.3 (2C), 139.5, 158.7, 160.5 (2C). LC-MS m/z 271.136. (M+H) ${ }^{+}$.

\section{Cell culture and treatment solutions}

MCF-7 and MCF-10A cells, obtained from Cell Bank of Rio de Janeiro, were cultured in complete medium containing DMEM+HAMF10 medium (1:1, v/v), supplemented with $10 \%$ of fetal bovine serum and antibiotic mixture penicillin/ streptomycin $(10 \mathrm{~mL} / \mathrm{L})$ plus kanamycin sulfate $(10 \mathrm{mg} / \mathrm{L})$ using culture bottles of $25 \mathrm{~mm}^{2}$ or multiple well plates when necessary. The cells were incubated at $37^{\circ} \mathrm{C}$ under an atmosphere saturated with $5 \%$ of $\mathrm{CO}_{2}$.

The cis-TMS and trans-TMS were synthesized as previously reported (Mizuno et al., 2008). The compounds were dissolved in dimethyl sulfoxide (DMSO) into a stock concentration of $0.01 \mathrm{M}$. The final concentration of DMSO in culture was $0.1 \%$. Doxorubicin (DOX, $0.5 \mu \mathrm{M}$ ) (SigmaAldrich) was a positive control. All reagents were dissolved just before use and protected from light.

\section{Cytotoxicity assay - XTT}

Cytotoxicity assay used the Cell Proliferation Kit (Roche Applied Science). On a 96 wells plate, $10^{4}$ cells/well were seeded and incubated in an atmosphere of $5 \% \mathrm{CO}_{2}$ at $37{ }^{\circ} \mathrm{C}$ for $24 \mathrm{~h}$. After this period, the cells were exposed to different concentrations of cis-TMS and trans-TMS (7.8 to $1000 \mu \mathrm{M})$, $0.5 \mu \mathrm{M}$ of doxorubicin, or $0.1 \%$ of DMSO. Doxorubicin and DMSO were positive and vehicle control, respectively. The cells were incubated for an additional $24 \mathrm{~h}$ and, the plate was washed with phosphate buffer saline (PBS 1x). The plate was then incubated with DMEM without phenol red plus the XTT/electron solution for $4 \mathrm{~h}$. Total absorbance was measured at 492 and $690 \mathrm{~nm}$. The number of viable cells was directly proportional to the absorbance and the percentage was compared with the negative control.

\section{Clonogenic survival assay}

The clonogenic assay was according to Franken et al. (2006). Briefly, 200 cells/well were seeded in six wells plates containing $2 \mathrm{~mL}$ of complete medium. After four hours, the cells were treated with different concentrations of trans-TMS $(2.5 \mu \mathrm{M}, 5 \mu \mathrm{M}$, and $10 \mu \mathrm{M})$ and cis-TMS $(0.3125 \mu \mathrm{M}, 0.625$ $\mu \mathrm{M}, 1.25 \mu \mathrm{M}, 2.5 \mu \mathrm{M}, 5 \mu \mathrm{M}$, and $10 \mu \mathrm{M})$ for $24 \mathrm{~h}$. After this period, each well was washed with PBS 1x, completed with medium, and allowed to grow for 7-14 days, when the colonies were visible. The cells were fixed with a mixture of methanol/ acetic $\mathrm{acid} /$ water $(1: 1: 8, \mathrm{v} / \mathrm{v} / \mathrm{v})$ for $30 \mathrm{~min}$ and stained with Giemsa/Sörensen phosphate buffer (1:20, v/v) for 15 to 30 min. The colonies were counted using a stereomicroscope, and the cell survival fraction was calculated as a percentage compared to the negative control.

\section{Genotoxicity - comet assay}

The alkaline comet assay evaluated the genotoxicity. Ten thousand cells/well were seeded in 12 wells plates, and after $24 \mathrm{~h}$, treated with different concentrations of transTMS and cis-TMS for four hours. After treatments, $20 \mu \mathrm{L}$ of cell suspension was mixed with $200 \mu \mathrm{L}$ of low melting point agarose $(0.5 \%)$. This cell suspension/agarose mixture was poured on the previously coated slides with agarose $(1.5 \%)$ and covered with a coverslip. After solidification, the coverslip was removed, and the slides were placed in a cold lysis solution ( $\mathrm{NaCl} 2.5 \mathrm{M}, \mathrm{Na}_{2}$ EDTA $100 \mathrm{mM}$, Tris $10 \mathrm{mM}$, Triton X-100 1\%, and DMSO 10\%, pH 10.0) for at least two<smiles>COc1ccc(/C=C\c2cc(OC)cc(OC)c2)cc1</smiles>

\section{(Z)-1,3-dimethoxy-5-(4-methoxystyryl)benzene cis-TMS}

Figure 1 - Chemical structure of cis- and trans-TMS<smiles>COc1ccc(/C=C/c2cc(OC)cc(OC)c2)cc1</smiles>

(E)-1,3-dimethoxy-5-(4-methoxystyryl)benzene trans-TMS 
hours. Then, they were incubated in alkaline buffer $(\mathrm{NaOH}$ $0.3 \mathrm{M}$, and $\mathrm{Na}_{2}$ EDTA $1 \mathrm{mM}, \mathrm{pH}>13$ ) at $4{ }^{\circ} \mathrm{C}$ for $20 \mathrm{~min}$ and submitted to electrophoresis for $30 \mathrm{~min}$ at $25 \mathrm{~V} 300 \mathrm{~mA}$. The slides were incubated in a neutralization buffer for $15 \mathrm{~min}$ (Tris- $\mathrm{HCl} 0.4 \mathrm{M}, \mathrm{pH} 7.5$ ) and fixed with $15 \% \mathrm{CCl}_{3} \mathrm{COOH}$, $5 \% \mathrm{ZnSO}_{4} 7 \mathrm{H}_{2} \mathrm{O}$ and $5 \% \mathrm{C}_{3} \mathrm{H}_{8} \mathrm{O}_{3}$ for $10 \mathrm{~min}$. All slides were stained using silver nitrate as described by Nadin et al. (2001). A total of 150 nucleoids were analyzed per treatment according to the level of DNA migration (Tice et al., 2000).

\section{Analysis of cell cycle}

For cell cycle kinetics, $5 \times 10^{4}$ cells/wells were seeded in 12 wells plate, and after $24 \mathrm{~h}$, the cells were treated for an additional $24 \mathrm{~h}$ with $2.5 \mu \mathrm{M}$ of cis-TMS or $10 \mu \mathrm{M}$ of transTMS. The cells were harvested and stained with propidium iodide to determine the different phases of the cell cycle by flow cytometry using the Flow Cytometry BD FACSCanto (BD Biosciences, USA).

\section{Determination of apoptotic cells fraction}

The fraction of apoptotic cells was determined by flow cytometry. For this assay, $2 \times 10^{4}$ cells/well were seeded in 12 wells plate. After $24 \mathrm{~h}$, the cells were treated with $2.5 \mu \mathrm{M}$ of cis-TMS or $10 \mu \mathrm{M}$ of trans-TMS and incubated for $24 \mathrm{~h}$. Then, the cells were harvested and processed according to the manufacturer's instructions using the Dead Cells Apoptosis Kit (Thermo Fisher Scientific, USA). The apoptotic cell frequency was determined using the Guava ${ }^{\circledR}$ EasyCyte ${ }^{\mathrm{TM}}$ (GE Healthcare, NJ, USA). By this procedure, early apoptotic cells are Annexin V-positive and PI-negative (Annexin V-FITC+/ $\mathrm{PI}-$ ), whereas late (end-stage) apoptotic cells are Annexin V/PI-double-positive (Annexin V-FITC+/PI+) (Wlodkowic et al., 2011).

\section{Statistical analysis}

All statistical analyses were performed using GraphPad Prism 5.0 software. Analysis of variance (ANOVA), followed by Bonferroni post-test, compared the experimental groups. Statistically significant values were those with $p \leq 0.05$, and the results were reported as means and standard deviations (SD) of three independent experimental samples. Negative control (NC) and vehicle control (VC) did not exhibit statistical differences; therefore, treatments were compared to the vehicle (VC).

\section{Results}

\section{The cytotoxicity of cis and trans-TMS}

Figures $2 \mathrm{~A}$ and $\mathrm{B}$ exhibit the results of cell viability analysis obtained by XTT assay after $24 \mathrm{~h}$ of treatment with different cis- and trans-TMS concentrations. Both compounds caused a significant reduction of cell viability at all tested concentrations in both cell lines $(p<0.0001 v s$. VC). Both substances showed concentration-dependent cytotoxic activity and were not selective between MCF-7 and MCF-10A cells since no statistical differences were detected between both cell lines. The calculated inhibitory concentration (IC50) was 42.2 and $59.5 \mu \mathrm{M}$ for cis- and trans-TMS in MCF-7 and, 16.2 $\mu \mathrm{M}$ and $45.7 \mu \mathrm{M}$ in MCF-10A for cis- and trans-TMS, respectively.

To analyze the long-term cytotoxicity of the two stilbenes, we performed the clonogenic survival assay. The chosen concentration range was based on the XTT results described above and on the concentrations used to determine the survival fraction as we previously described (Mizuno et al., 2017). Therefore, the concentrations of $0.31 \mu \mathrm{M}, 0.62$ $\mu \mathrm{M}, 1.25 \mu \mathrm{M}, 2.5 \mu \mathrm{M}, 5 \mu \mathrm{M}$, and $10 \mu \mathrm{M}$ were chosen for the assay with the cis-TMS, while for the trans-TMS, the concentrations of $2.5 \mu \mathrm{M}, 5 \mu \mathrm{M}$, and $10 \mu \mathrm{M}$ were selected. Treatment of the cells with cis-TMS significantly reduced the survival fraction of MCF-7 cells in concentrations higher than $2.5 \mu \mathrm{M}(p<0.001)$ (Figure 3A). In MCF-10A, the cis-TMS reduced the survival fraction in all tested concentrations $(p<$ 0.001 ) (Figure 3A). Treatments with trans-TMS showed no significant reduction in cell survival fraction at all the tested concentrations in both cell lines (Figure 3B).

\section{DNA damage analysis}

The genotoxicity was analyzed using the alkaline version of comet assay 4 hours after treatment with cis- or trans-TMS in both cell lines (Figure 4). Treatments with 1.25 and 2.5 $\mu \mathrm{M}$ cis-TMS significantly increased the DNA damage score in MCF-7 ( $p<0.01$ and 0.001, respectively) and MCF-10A $(p<0.05)$ (Figure 4A), while trans-TMS at 5 and $10 \mu \mathrm{M}$ increased the DNA damage score only in MCF-10A cells $(p$ $<0.05$ ) (Figure 4B).

\section{Cell cycle and cell death analysis}

Figure 5 exhibits the distribution of cells in different phases of the cell cycle after treatment with $2.5 \mu \mathrm{M}$ of cis- or $10 \mu \mathrm{M}$ of trans-TMS. The treatment with cis- or trans-TMS significantly reduced the frequency of G1 cells and notably increased the frequency of G2-M cells in both cell lines compared to the negative control $(p<0.05)$. No statistical differences in response to the treatments were observed comparing the MCF-7 and MCF-10A cells.

Figure 6 shows the results of cell death rates after treatment with cis- or trans-TMS. The frequency of apoptosis (Figure 6A) and necrosis (Figure 6B) was significantly higher in MCF-7 and MCF-10A cells treated with cis- or trans-TMS than in the negative control. The frequency of apoptosis in MCF-7 was 48.7 and $27.1 \%$ after treatment with cis- or trans-TMS, respectively, while MCF-10A exhibited 30.5 and $27.6 \%$ of apoptosis, respectively (Figure $6 \mathrm{~A}$ ). No difference in the frequency of necrotic cells between both cell lines was observed (Figure 6B).

\section{Discussion}

In the present study, the antiproliferative effects of two stilbene derivatives, cis- and trans-TMS, were evaluated and compared in the tumoral breast cell line MCF-7 and its normal counterpart MCF-10A. Previous cytotoxicity screening of these stilbenes in different cancer cell lines revealed MCF-7 as the most sensitive to the treatment with cis-and trans-TMS (non-published data).

The treatment with cis- and trans-TMS reduced the cellular viability of both cell lines, as demonstrated by the XTT assay. The calculated $\mathrm{IC}_{50}$ revealed higher cytotoxicity of cis- than trans-TMS. However, while relative $\mathrm{IC}_{50}$ values may have predictive value in comparing a series of compounds with a similar mode of action, absolute $\mathrm{IC}_{50}$ values do not predict cell survival (Brown and Wouters, 1999). This is clearly 


\section{cis-TMS}

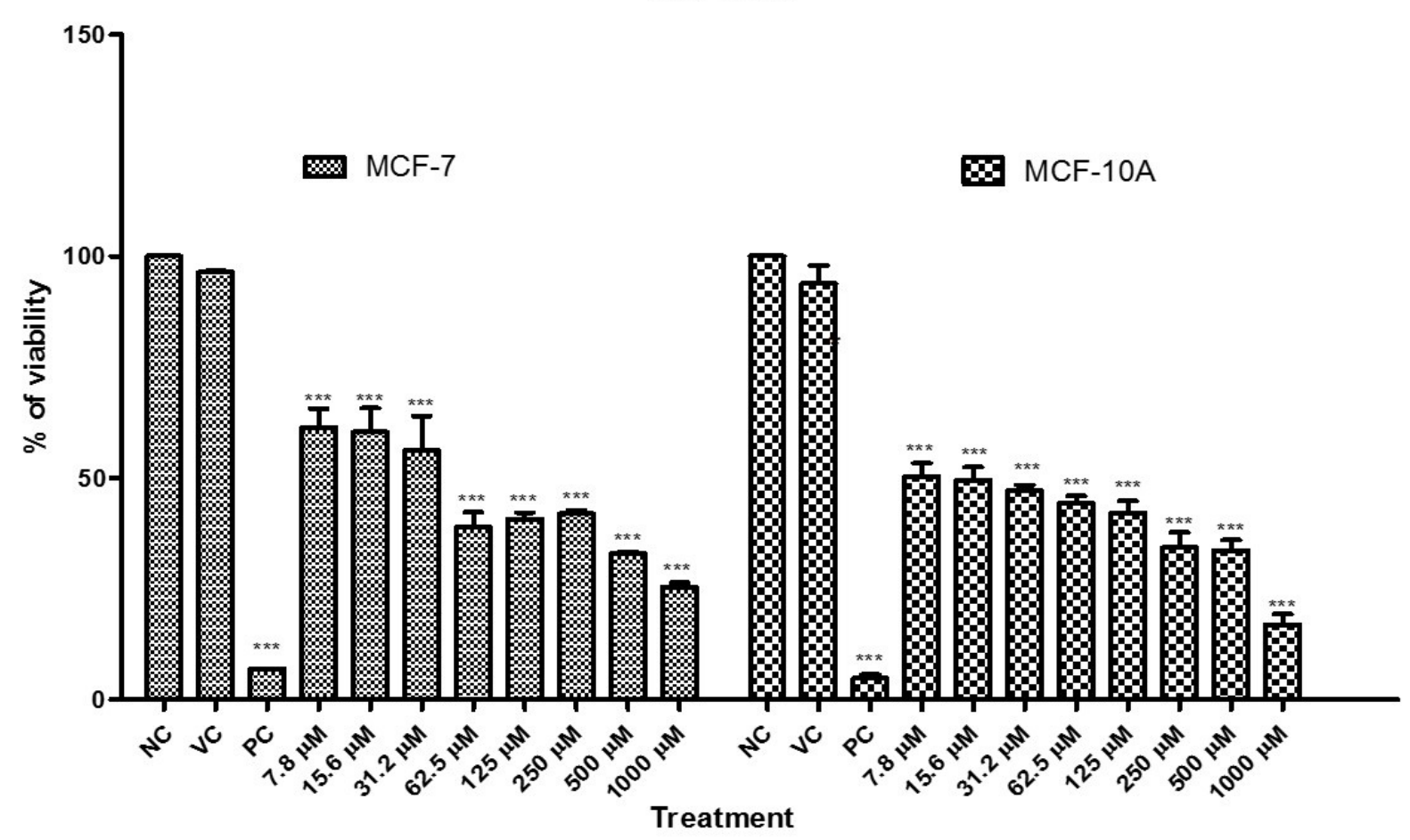

(A)

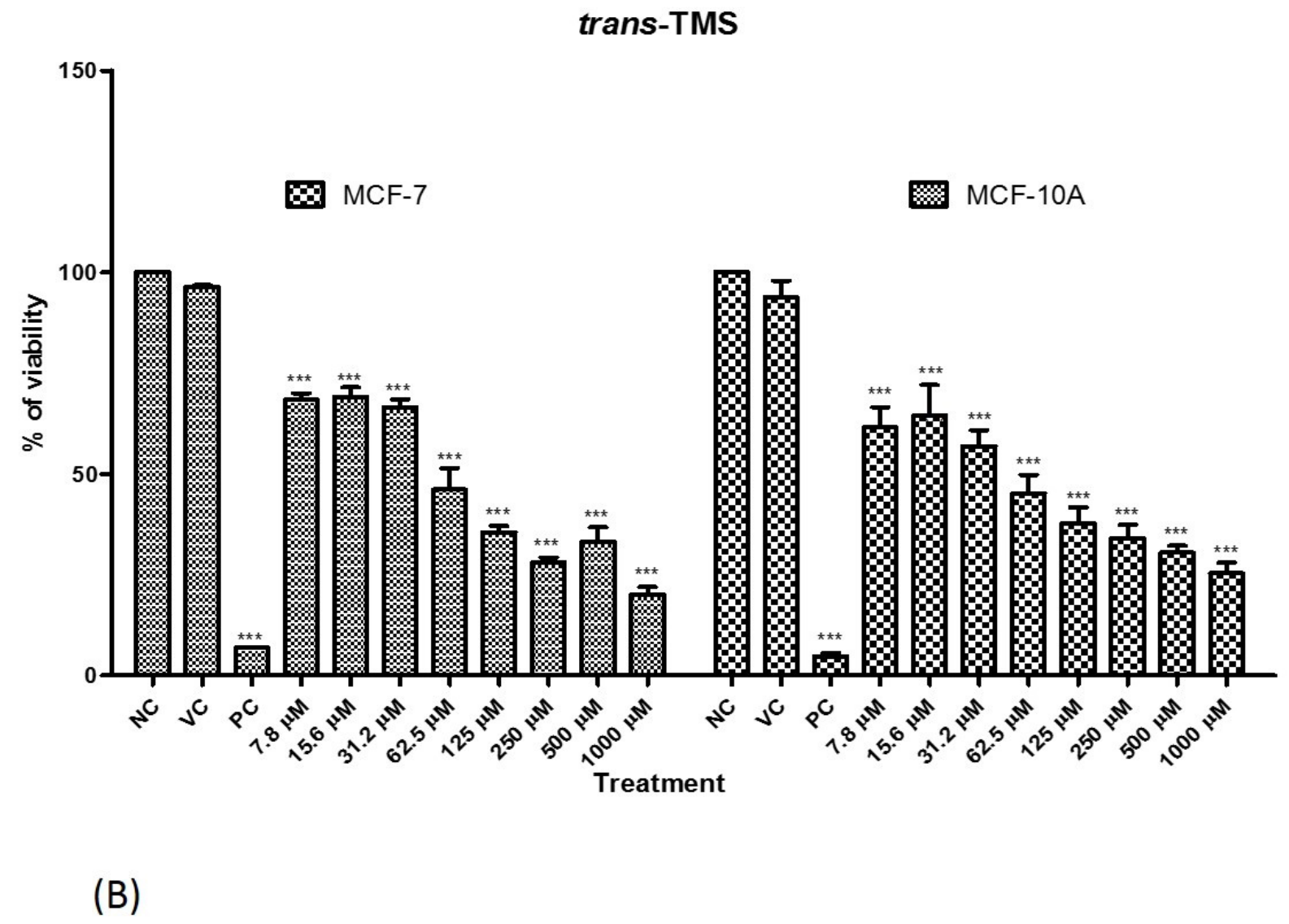

Figure 2 - Percentage of cell viability obtained by XTT assay in MCF-7 and MCF-10A cells treated with different concentrations of cis- (A) or transTMS (B). NC: negative control; VC: vehicle control; PC: positive control; *** $P<0.001$ (vs NC). 

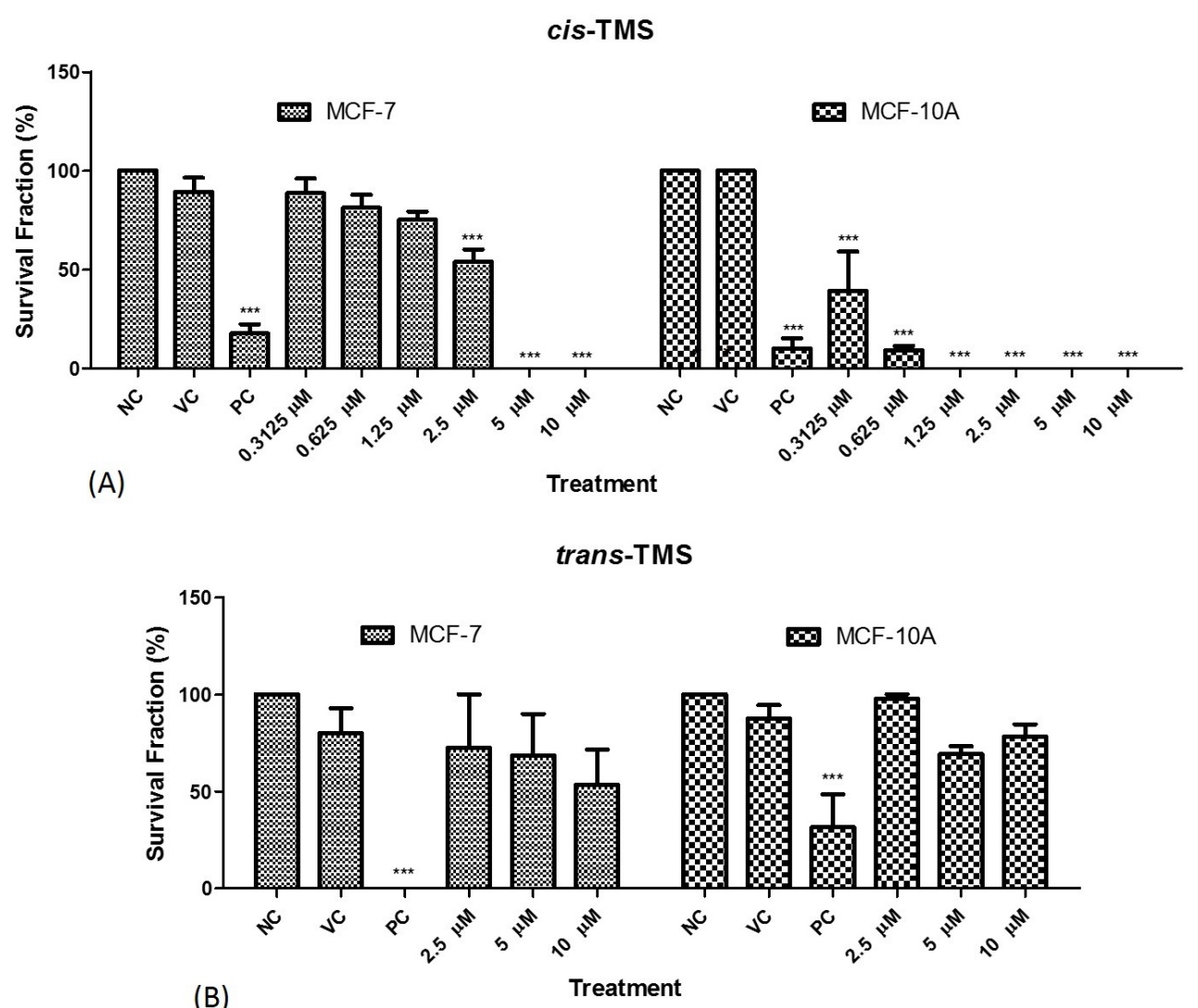

Figure 3 - Survival fraction obtained in MCF-7 and MCF-10A cells treated with different concentrations of cis- (A) or trans-TMS (B). NC: negative control; VC: vehicle control; PC: positive control; *** $P<0.001$ ( $v s \mathrm{NC}$ ).
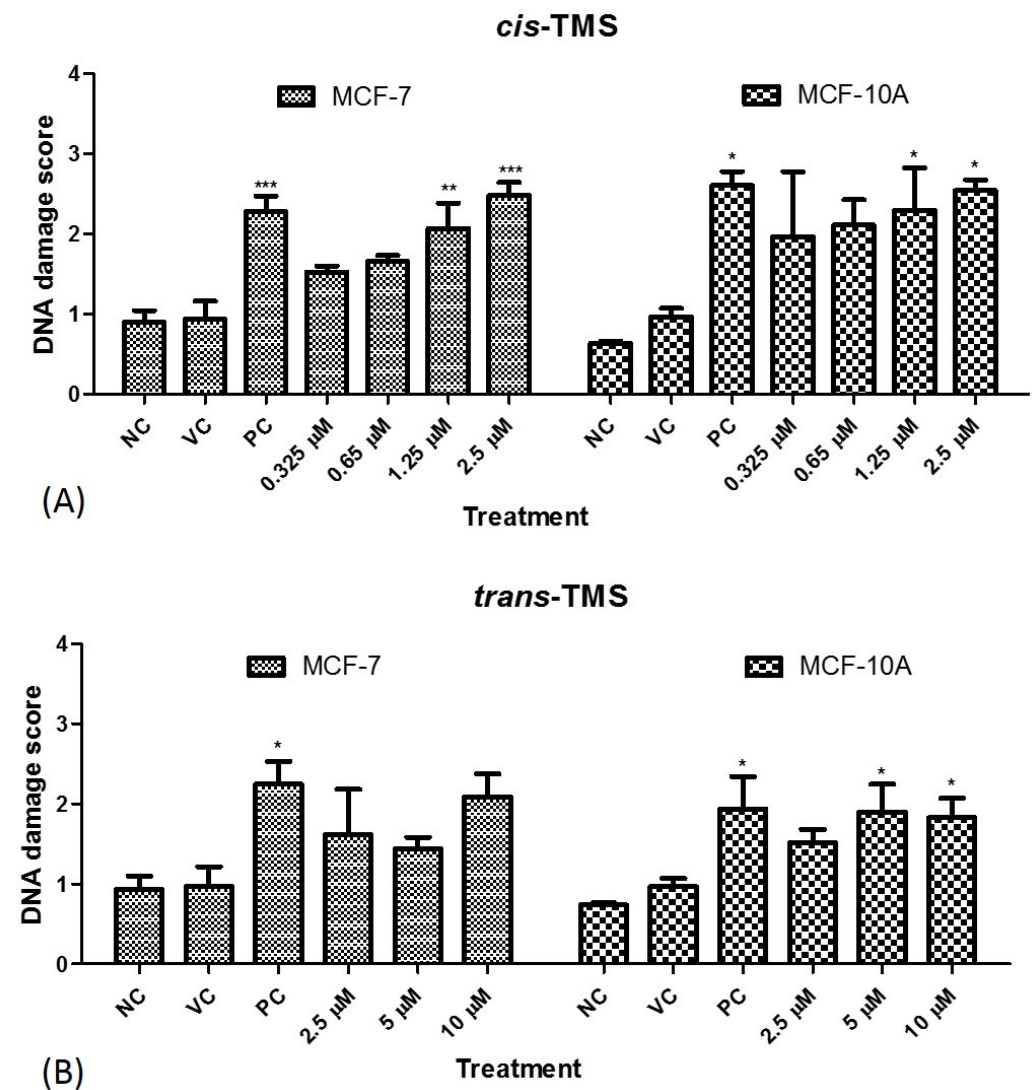

Figure 4 - DNA damage obtained by comet assay in in MCF-7 and MCF-10A cells treated with different concentrations of cis- (A) or trans-TMS (B). NC: negative control; VC: vehicle control; PC: positive control; * $P<0.05$ (vs NC); $* * P<0.01(v s$ NC); *** $P<0.001$ (vs NC). 
MCF-7

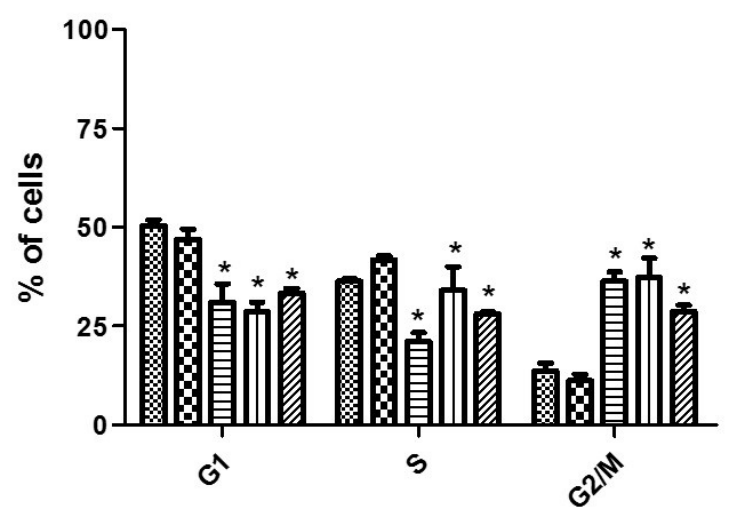

MCF-10A

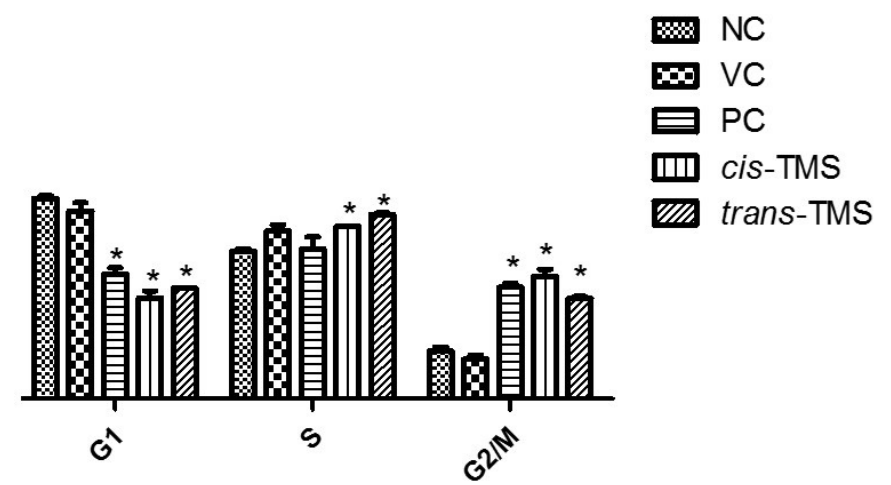

Figure 5 - Distribution of MCF-7 (A) and MCF-10A(B) in different phases of cell cycle after treatment with cis-TMS (2.5 $\mu \mathrm{M})$ or trans-TMS (10 $\mu \mathrm{M})$. NC: negative control; VC: vehicle control; PC: positive control; * $P<0.05$ ( $v s \mathrm{NC}$ ).

APOPTOSIS

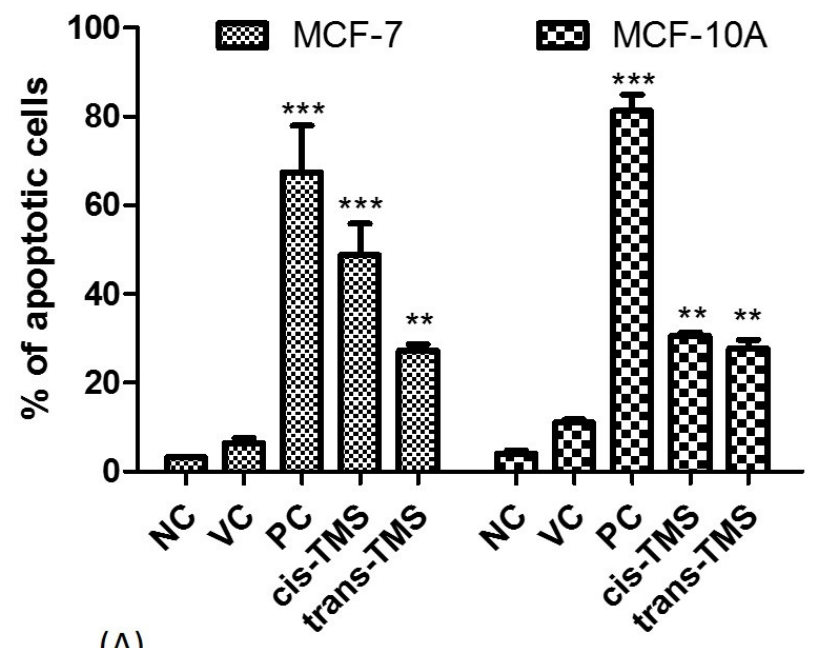

NECROSIS

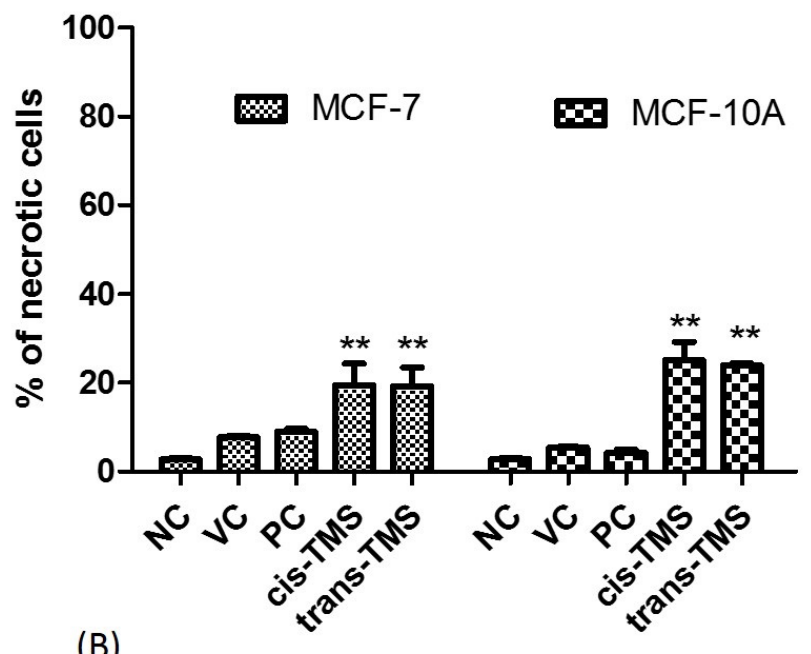

Figure 6 - Frequency of apoptotic (A) and necrotic (B) cells $24 \mathrm{~h}$ after treatment with cis-TMS (2.5 $\mu \mathrm{M})$ or trans-TMS (10 $\mu \mathrm{M})$. NC: negative control; VC: vehicle control; PC: positive control; ** $P<0.01$ (vs NC); *** $P<0.001$ (vs NC).

demonstrated by the survival fraction obtained after treatment with cis- or trans-TMS in both cell lines in the present study. Although the value of short-term cytotoxicity assays is based on tetrazolium salts to reveal the fraction of still metabolically active cells, these non-clonogenic assays may underestimate the cytotoxicity of a compound. In addition, these assays can overestimate the cytotoxicity by not consider cells with reversible damage or resistance to the cytotoxic agent tested (Adan et al., 2016). Loss of tumor cell reproductive viability, measurable in many cell lines by clonogenic survival assays, is the most direct method of measuring a drug's cytotoxic activity (Puck and Marcus, 1955). Therefore, the clonogenic survival assay measures the long-term cytotoxic effects of a molecule by measuring the proliferative capacity of a single cell to form a clone and thereby produce a viable colony (Sumatran, 2011).

According to our results, even low concentrations of the cis-TMS inhibited the colony formation, while trans-TMS did not reduce the survival fraction to statistically significant levels. The reduction of the survival fraction after cis-TMS treatment could be related to its genotoxicity. In the presence of DNA damage that cannot be repaired, p53 protein may activate the DNA damage response pathway modulating the cell cycle progression or triggering apoptosis to prevent the replication of damaged chromosomes (Williams and Schumacher, 2016). Both cis- and trans-TMS increased the extension of DNA damage in both cell lines, but while the cis- was genotoxic to both cell lines, the trans-TMS increased the DNA damage score only in MCF-10A and in concentrations two or four times higher than the cis.

Since both cis-TMS and trans-TMS displayed cytotoxic and genotoxic effects, the ability of these two substances to modulate the cell cycle kinetics and induce cell death was investigated. Both stilbenes caused an accumulation of cells in the $\mathrm{G} 2$ phase and increased the frequency of apoptosis in MCF-7 and MCF-10A. The accumulation of both cell lines in the G2-M phase may be related to the genotoxicity of the 
substances since the induction of DNA damage during the S phase can lead to the G2-M cell cycle arrest and subsequent death by apoptosis. Treatment of hepatoma-derived cell lines with $1 \mu \mathrm{M}$ of $c i s$-TMS during $48 \mathrm{~h}$ induced accumulation in the G2-M phase with a concomitant reduction in G1 and S phases (Nguyen et al., 2016). These effects were attributed to the downregulation of total cyclin-dependent kinase 1 (CDK1) with concomitant induction of $\mathrm{p} 21^{\mathrm{Cip} / \text { Wafl }}$ expression. TransTMS at $80 \mu \mathrm{M}$ also stalled HCT116 cancer cells in G2-M with subsequent cell death (Traversi et al., 2019). There is strong evidence in the literature that the effects of TMS inhibit tubulin polymerization during the S phase, which leads to the destabilization of microtubule activity and consequent cell cycle delay and death (Chabert et al., 2006; Traversi et al., 2016; Traversi et al., 2017).

Our results demonstrated that cis- and trans-TMS induced apoptosis in both cell lines. Apoptosis can occur in response to different situations, including after cell damage by genotoxicity caused by chemotherapeutic agents (Grivicich et al., 2007). Our data suggest that the genotoxic effects of cisand trans-TMS are related to cell cycle arrest and apoptosis.

When considering the overall results of the present study it is clear that cis- and trans-TMS are not selective between MCF-7 and MCF-10A and that the cellular response to cisTMS occurs in concentrations four times lower than transTMS. Cis- and trans-TMS are geometric isomers. They are non-superimposable, non-mirror images of each other. They result from the restricted rotation of a carbon-carbon bond. The two enantiomers of a chiral drug may differ significantly in their bioavailability, rate of metabolism, metabolites, excretion, potency, selectivity for receptors, transporters, and enzymes, and toxicity, leading to the choice for a singleenantiomer drug with more straightforward and more selective pharmacologic profiles, improved therapeutic indices and simpler pharmacokinetics (McConathy and Owens, 2003).

In conclusion, the present results suggest that the genotoxicity of both compounds may be involved in the antiproliferative effects observed in MCF-7 and MCF-10A cell lines. However, this effect is considerably more pronounced for cis-TMS.

\section{Acknowledgments}

The present study was supported be the Brazilian funding agencies São Paulo Research Foundation (FAPESP; grants 2014/12465-0; 2018/16461-0), National Council for Scientific and Technological Development (CNPq, fellowship to R. A. Santos 307307/2014), and Coordination for the Improvement of Higher Education Personnel (CAPES; Finance Code 001). The authors are grateful to Dr. Anderson Roberto de Souza for helping with flow cytometry analysis.

\section{Conflict of Interest}

The authors declare no conflict of interest.

\section{Author Contributions}

NSG developed the project, designed the experimental approaches, performed data and statistical analysis, and worked in manuscript writing. TMSPM performed some experiments and data interpretation. CSM developed and performed the structural modification, and worked in data interpretation and manuscript writing. SH performed and analyzed NMR experiments. RAS coordinated and designed the experiments, analyzed and interpreted the data and revised the final form of the manuscript.

\section{References}

Adan A, Kiraz Y and Baran Y (2016) Cell proliferation and cytotoxicity assays. Curr Pharm Biotech 17:1213-1221.

Almaliti J, Nada SE, Carter B, Shah ZA and Tillekeratne LM (2013) Natural products inspired synthesis of neuroprotective agents against $\mathrm{H} 2 \mathrm{O} 2$-induced cell death. Bioorg Med Chem Lett 23:1232-1237.

Brown JM, Wouters BG (1999) Apoptosis, p53, and tumor cell sensitivity to anticancer agents. Cancer Res 59:1391-1399.

Chabert F, Fougerousse A and Brouillard R (2006) Anti-mitotic propoerties of resveratrol analog $(Z)-3,5,4^{\prime}$-trimethoxystilbene. BioFactors 27:37-46.

Connor MJ (2015) Targeting the DNA damage response in cancer. Mol Cell 60:547-560.

Cragg GM and Newman DJ (2016) Natural products as sources of new drugs from 1981 to 2014. J Nat Prod 79:629-661.

Elshaer M, Chen Y, Wang XJ and Tang X (2018) Resveratrol: An overview of its anti-cancer mechanisms. Life Sciences 207:340-349.

Franken NAP, Rodermond HM, Stap J, Haveman J and Van Bree C (2006) Clonogenic assay of cells in vitro. Nat Protoc 1:2315-2319.

Fulda S (2010). Resveratrol and derivatives for the prevention and treatment of cancer. Drug Discov Today 15:757-765.

Grivicich I, Regner A and Rocha AB (2007) Morte celular por apoptose. Rev Bras Cancerol 53:335-343.

Intagliata S, Modica MN, Satagati LM, Montenegro L (2019) Strategies to improve resveratrol systemic and topical bioavailability: An update. Antioxidants 8:244.

Lin SR, Fu YS, Tsai MJ, Cheg H and Weng CF (2017) Natural compounds from herbs that can pottentially execute as autophagy inducers for cancer therapy. Int J Mol Sci 18:1412.

McConathy J and Owens MJ (2003) Stereochemistry in drug action. Prim Care Companion J Clin Psychiatry 5:70-73.

Mikstacka R, Zielinska-Przyjemska M, Dutkiewicz Z, Cichocki M, Stefanski T, Kaczmarek M and Baer-Dubowska W (2018) Cytotoxic, tubulin-interfering and proapoptotic activies of 4'-methylthio-trans-stilbene derivatives, analogues of transresveratrol. Cytotechnol 70:1349-1362.

Mizuno CS, Ampomaah W, Mendonça FR, Andrade GC, Silva AMN, Goulart MO and Santos RA (2017) Cytotoxicity and genotoxicity of stilbene derivatives in $\mathrm{CHO}-\mathrm{K} 1$ and $\mathrm{HepG} 2$ cell lines. Genet Mol Biol 40:656-664.

Mizuno CS, Ma, G, Khan S, Patny A, Avery MA and Rimando AM (2008) Design, synthesis, biological evaluation and docking studies of pterostilbne analogs inside PPARalpha. Bioorg Med Chem 16:3800-3808.

Nadin SB, Vargas-Roig LM and Ciocca DR (2001) A silver staining method for single-cell gel assay. J Histochem Cytochem 49:1183-1186

Nguyen CB, Kotturi H, Waris G, Mohammed A, Chandrakesan P, May R, Sureban S, Weygant N, Qu D, Rao CV et al. (2016) (Z)-3,5,4'-trimethoxystilbene limits hepatitis $\mathrm{C}$ and cancer pathophysiology by blocking microtubule dynamics and cellcycle progression. Cancer Res 76:4887-4896.

Paul S, Mizuno CS, Lee HJ, Zheng X, Chajkowisk S, Rimoldi JM, Conney A, Suh N and Rimando AM (2010) In vitro and in vivo studies on stilbene analogs as potential treatment agents for colon cancer. Eur J Med Chem 45:3702-3708. 
Puck TT, Marcus PIA (1955) A rapid method of viable cell titration and clone production with HeLa cell in tissue culture: The use of X-irradiated cells to supply conditioning factors. Proc Natl Acad Sci U S A 41:432-437.

Rivière C, Pawlus AD and Mérillon JM (2012) Natural stilbenoids: Distribution in the plant kingdom and chemotaxonomic interest in Vitaceae. Nat Prod Rep 29:1317-1333.

Shukla Y and Singh R (2011) Resveratrol and cellular mechanisms of cancer prevention. Ann N Y Acad Sci 1215:1-8.

Sumatran VN (2011) Cellular chemosensitivity assays: An overview. Methods Mol Biol 731:219-236.

Tian B, Liu J (2020) Resveratrol: A review of plant sources, synthesis, stability, modification and food application. Sci Food Agric 100:1392-1404.

Tice RR, Agurell E, Anderson D, Burlinson B, Hartmann A, Kobayashi H, Miyamae Y, Rojas E, Ryu JC and Sasaki YF (2000) Single cell gel/comet assay: Guidelines for in vitro and in vivo genetic toxicology testing. Environ Mol Mutagen 35:206-221.

Traversi G, Fiore M, Leone S, Basso E, Di Muzio E, Polticelli F, Degrassi F and Cozzi R (2016) Resveratrol and its methoxyderivatives as modulators of DNA damage induced by ionising radiation. Mutagenesis 31:433-441.
Traversi G, Fiore M, Percario Z, Degrassi F and Cozzi R (2017) The resveratrol analogue trimethoxystilbene inhibits cancer cell growth by inducing multipolar cell mitosis. Mol Carcinog 56:1117-1126.

Traversi G, Staid DS, Fiore M, Percario Z, Trisciuoglio D, Antonioletti R, Morea V, Degrassi F and Cozzi R (2019) A novel resveratrol derivative induces mitotic arrest, centrosome fragmentation and cancer cell deatu by inhibiting $\gamma$-tubulin. Cell Div 14:3.

Williams AB, Schumacher B (2016) p53 in the DNA-damage-repair process. Cold Spring Harbor Persp Med 6:a026070.

Wlodkowic D, Telfor W, Skommer J, Darzynkiewicz Z (2011) Apoptosis and beyond: Cytometry in studies of programmed cell death. Methods Cell Biol 103:55-98.

Associate Editor: Luis Mariano Polo

License information: This is an open-access article distributed under the terms of the Creative Commons Attribution License (type CC-BY), which permits unrestricted use, distribution and reproduction in any medium, provided the original article is properly cited. 